\title{
Analysis of a correlation between the $B R A F$ V600E mutation and abnormal DNA mismatch repair in patients with sporadic endometrial cancer
}

\author{
MAKIKO KAWAGUCHI, MEGUMI YANOKURA, KOUJI BANNO, YUSUKE KOBAYASHI, \\ YOSHIKO KUWABARA, MAYA KOBAYASHI, HIROYUKI NOMURA, \\ AKIRA HIRASAWA, NOBUYUKI SUSUMU and DAISUKE AOKI \\ Department of Obstetrics and Gynecology, Keio University School of Medicine, Tokyo, Japan
}

Received January 22, 2009; Accepted March 11, 2009

DOI: 10.3892/ijo_00000283

\begin{abstract}
Point mutations of KRAS and BRAF genes are thought to be important in carcinogenesis of colon cancer. In particular, gene instability caused by decreased expression of the $h M L H 1$ gene, a DNA mismatch repair (MMR) gene, may be linked to the activating $B R A F \mathrm{~V} 600 \mathrm{E}$ point mutation in sporadic colon cancer. However, a consensus has not been established regarding the correlation between point mutations of $K R A S$ or $B R A F$ and carcinogenesis in patients with endometrial cancer, which is closely related to colon cancer. Therefore, we analyzed aberrant hypermethylation of the $h M L H 1$ gene, microsatellite instability (MSI), and point mutations of KRAS and BRAF in 44 samples of sporadic endometrial cancer, with the aim of examining the mechanism of carcinogenesis in patients with endometrial cancer. Aberrant hMLH1 hypermethylation was found in 17 of the 44 cases $(38.6 \%)$ and showed a significant positive correlation with MSI $(\mathrm{p}=0.02)$. This suggests that an abnormal MMR mechanism plays an important role in carcinogenesis of sporadic endometrial cancer. Point mutation of KRAS was found in 6 of the 44 cases (13.6\%), but no BRAF V600E mutation was detected. These data suggest that the BRAF V600E mutation is not the target gene for abnormal MMR in carcinogenesis in patients with sporadic endometrial cancer, unlike in colon cancer. This is supported by the relatively few previous reports indicating a correlation between endometrial cancer and the BRAF V600E mutation. Identification of new candidates for the target gene for abnormal MMR in endometrial cancer requires further work.
\end{abstract}

Correspondence to: Dr Kouji Banno, Department of Obstetrics and Gynecology, Keio University School of Medicine, 35 Shinanomachi, Shinjuku-ku, Tokyo 160-8582, Japan

E-mail:kbanno@sc.itc.keio.ac.jp

Key words: endometrial cancer, BRAF, KRAS, hMLH1, microsatellite instability

\section{Introduction}

A cancer may develop as a result of repeated mutation of genes involved in differentiation or proliferation. Such a multistep mechanism of carcinogenesis with mutation of multiple cancer-related genes is often observed in patients with colon cancer. The correlation between colon cancer carcinogenesis and point mutation of $R A S / R A F$ genes in the MAP kinase pathway suggests that these genes have an important role at an early stage of malignant alteration of colon cancer (1).

Endometrial cancer has many similarities with colon cancer and is detected at high rates as a double cancer of hereditary non-polyposis colon cancer (HNPCC). Germline mutation of $h M L H 1$, a DNA mismatch repair (MMR) gene, occurs at high rates in HNPCC patients (2), and decreased expression of $h M L H 1$ due to aberrant hypermethylation has also been found in patients with sporadic colon cancer and endometrial cancer (3). Decreased expression of $h M L H 1$ due to epigenetic changes may facilitate gene replication errors and cause gene instability, which can be detected as microsatellite instability (MSI) (4). Microsatellite DNA is a region with short repeated sequences of 1-2 bases, and PCR-based detection of replication errors in this region has been used widely as a clinical test to examine gene instability. Such instability may cause mutation of cancerrelated genes, and a correlation between MSI due to decreased $h M L H 1$ expression and point mutations of KRAS and BRAF genes has been proposed in patients with colon cancer $(5,6)$.

Mutation of the $B R A F$ gene has been found in many human cancers, including colon cancer, malignant melanomas, thyroid carcinoma and ovarian carcinoma (7-9). BRAF is one of the 3 subtypes of $R A F$ family genes and encodes a tyrosine kinase involved in mitogenic signaling in the RAS-RAF-MEK-ERK$M A P$ kinase pathway. The function of $R A F$ is regulated by $R A S$, and an activating point mutation of $B R A F$ causes unregulated constitutive activation of the tyrosine kinase activity and facilitates cell proliferation via the $M A P$ kinase pathway. The V600E mutation in exon 15 of $B R A F$ is of particular interest, since tyrosine kinase activity 10 -fold that of wildtype has been found in tumor tissue with this mutation (10). The V600E mutation is found in about $15 \%$ of patients with sporadic colon cancer and can be used for clinical diagnosis of non-inheritive sporadic colon cancer (10). Furthermore, since $B R A F$ V600E is observed in $32 \%$ of cases of MSI-positive 
Table I. Primer sequences used in PCR and MSP analysis.

\begin{tabular}{llllrl}
\hline Gene & PCR method & \multicolumn{1}{c}{ Sense } & Antisense & $\begin{array}{r}\text { Size } \\
(\mathrm{bp})\end{array}$ & $\begin{array}{c}\text { Annealing } \\
\left({ }^{\circ} \mathrm{C}\right)\end{array}$ \\
\hline hMLH1 & Methylated & ACGTAGACGTTTTATTAGGGTCGC & CCTCATCGTAACTACCCGCG & 112 & 60 \\
& Unmethylated & TTTTGATGTAGATGTTTATTAGGGTTGT & ACCACCTCATCATAACTACCCACA & 124 & 60 \\
& & & TTATCTGTATCAAAGAATGGTC & 180 & 64 \\
KRAS & Codons 12,13 & GCCTGCTGAAAATGACTGAAT & GGCCAAAAATTTAATCAGTGGA & 150 & 60 \\
\hline
\end{tabular}

sporadic colon cancer and $75 \%$ of cases with sporadic colon cancer with aberrant hypermethylation of $h M L H 1, B R A F$ has been proposed as the target gene of abnormal MMR (11).

In contrast to colon cancer, only a few reports have shown mutation of $B R A F$ in patients with endometrial cancer. Feng et al found BRAF mutations in $21 \%$ of patients with endometrial cancer and suggested that the mutation correlated with decreased $h M L H 1$ expression (12). However, Salvesen et al found a BRAF mutation in only $2 \%$ of patients with endometrial cancer (13). Therefore, it is unclear whether mutation of BRAF is important in carcinogenesis of endometrial cancer and whether the mutation may be linked to abnormal expression of the $h M L H 1$ gene. In this study, we analyzed aberrant hypermethylation of $h M L H 1$, MSI, and mutations of $K R A S$ and $B R A F$ in patients with sporadic endometrial cancer to examine correlations among point mutations in $R A S / R A F$ family genes, abnormal MMR caused by aberrant $h M L H 1$ hypermethylation, and carcinogenesis of sporadic endometrial cancer.

\section{Materials and methods}

Cell lines. Eight cell strains were used in the study: HEC108, Ishikawa (a human endometrial cancer-derived cultured cell line supplied by Dr Hiroyuki Kuramoto); HOOUA and HHUA (supplied by Dr Isamu Ishiwata); and SNG-II, SNG-M, HEC-1B and KLE. KLE cells were cultured in a DMEM/F12 (1:1) medium (Gibco-BRL, Rockville, MD, USA) supplemented with $10 \%$ fetal bovine serum (FBS) (Sanko Junyaku Co., Tokyo, Japan). All other cells were cultured in 10\% FBSsupplemented F12 medium (Sigma, St. Louis, MO, USA). The cells were incubated in a dish of $10 \mathrm{~cm}$ in diameter under $5 \%$ $\mathrm{CO}_{2}$ at $37^{\circ} \mathrm{C}$.

Clinical specimens. The subjects were 44 patients with endometrial cancer $(\mathrm{G} 1,20 ; \mathrm{G} 2,11 ; \mathrm{G} 3,13)$ who gave informed consent to collection of cancer specimens. Of these patients, 37 had endometrioid adenocarcinoma and 7 had adenosquamous carcinoma. The grade of histological differentiation (G1-G3) and the cancer stage at surgery were determined based on the Guidelines for Endometrial Cancer published by the Japan Society of Obstetrics and Gynecology.

DNA extraction and methylation-specific PCR (MSP) in the $h M L H 1$ promoter region. DNA was extracted from the 44 endometrial cancer specimens using liquid-based cytology with a Get Pure DNA Kit (Dojindo Molecular Technologies, Inc., Kumamoto, Japan). Distilled water was added to $1 \mu \mathrm{g}$ of the extracted DNA up to a volume of $50 \mu 1$ and $5.5 \mu 1$ of $3 \mathrm{~N}$ $\mathrm{NaOH}$ solution was added. After mixing, the solution was incubated at $37^{\circ} \mathrm{C}$ for $15 \mathrm{~min}$, and then $520 \mu 1$ of $3 \mathrm{M}$ sodium bisulfite (Sigma) prepared at $\mathrm{pH} 5.5$ with $30 \mu \mathrm{l}$ of $10 \mathrm{mM}$ hydroquinone (Sigma) and $10 \mathrm{~N} \mathrm{NaOH}$ was added to the solution. After mixing in an upturned position to prevent vaporization, the solution was overlaid with mineral oil and incubated at $50^{\circ} \mathrm{C}$ overnight. Next, $1 \mathrm{ml}$ of clean-up resin (Promega, Madison, WI, USA) was added to the lower layer and the resulting solution was mixed in an upturned position and then injected into a column. The column was rinsed with $2 \mathrm{ml}$ of $80 \%$ isopropanol and then centrifuged at 15,000 rpm for $3 \mathrm{~min}$ to remove the isopropanol completely. Next, $50 \mu \mathrm{l}$ of distilled water $\left(70^{\circ} \mathrm{C}\right)$ was added directly to the column, which was then centrifuged at 15,000 rpm for 2 min to extract DNA adsorbed on the column. Then, $5.5 \mu 1$ of $2 \mathrm{~N} \mathrm{NaOH}$ was added to the resulting DNA solution. After mixing, the solution was incubated at $37^{\circ} \mathrm{C}$ for $20 \mathrm{~min}$, after which $66 \mu 1$ of $5 \mathrm{~N}$ ammonium acetate solution and $243 \mu 1$ of $95 \%$ ethanol were added and the solution was incubated at $80^{\circ} \mathrm{C}$ for $1 \mathrm{~h}$ and centrifuged at $15,000 \mathrm{rpm}$ for $30 \mathrm{~min}$ to precipitate DNA. Approximately $50 \mu 1$ of the supernatant was left in the tube. The rest of the supernatant was collected, mixed with $1 \mathrm{ml}$ of $70 \%$ ethanol, and then centrifuged at 15,000 rpm for $30 \mathrm{~min}$ to rinse the DNA. The precipitated DNA was air-dried and dissolved in $20 \mu \mathrm{l}$ of distilled water; $2 \mu \mathrm{l}$ of this solution was used as the MSP template solution. AmpliTaq Gold and 10X PCR buffer/ $\mathrm{MgCl}_{2}$ with dNTP (Applied Biosystems, Foster City, CA, USA) was used in PCR analysis and DNA was analyzed using a GeneAmp PCR System 9700 (Applied Biosystems). The PCR primer sequences are shown in Table I. DNA extracted from the cultured cell lines was also used in MSP analysis of $h M L H I$ (14).

Microsatellite instability analysis. Genomic DNA extracted from normal and tumor tissue samples from the 44 patients with endometrial cancer was PCR amplified at the microsatellite repeat loci D2S123, D5S346, D17S250, BAT26, BAT25, MSH3, MSH6, TGF-ßRII, BAX, MBD4A10 and MBD4A6, which include 3 dinucleotide (CA) and 8 mononucleotide repeats as microsatellite markers. PCR reactions were performed in a total volume of $25 \mu 1$ containing $10 \mathrm{X}$ buffer, $0.125 \mathrm{mM}$ deoxynucleoside triphosphate, $0.2 \mu \mathrm{M}$ of each primer, and 0.25 units of TaqDNA polymerase. The PCR 
conditions were as follows: $94^{\circ} \mathrm{C}$ for $10 \mathrm{~min} ; 30$ cycles at $94^{\circ} \mathrm{C}$ for $45 \mathrm{sec}, 58^{\circ} \mathrm{C}$ for $45 \mathrm{sec}$, and $72^{\circ} \mathrm{C}$ for $40 \mathrm{sec}$; followed by a final extension step at $72^{\circ} \mathrm{C}$ for $10 \mathrm{~min}$. After PCR, $1 \mu \mathrm{l}$ of the product was mixed with $12 \mu \mathrm{l}$ of loading buffer containing formamide and Rox size standards. This mixture was denatured at $95^{\circ} \mathrm{C}$ for $2 \mathrm{~min}$ and cooled on ice before loading onto an ABI PRISM 310 sequencer (Applied Biosystems). The results were analyzed using GeneScan software (Applied Biosystems). Tumors were classified as MSI-H when $\geq 30 \%$ of these markers showed MSI, in accordance with the recent recommendation of the National Cancer Institute Workshop. Low-frequency MSI ( $<30 \%$ of 11 markers) was included in the category of MSI-L and alteration of even one microsatellite region led to definition of the patient as MSI-positive (15).

Determination of KRAS and BRAF mutations. DNA was extracted from the 8 endometrial cancer-derived cell lines and 44 endometrial cancer specimens using liquid-based cytology with a Get Pure DNA Kit (Dojindo Molecular Technologies). Individual point mutations of the KRAS and $B R A F$ genes were documented using two gene-specific oligonucleotide primer pairs designed for PCR amplification of the region of the KRAS gene harboring codons 12 and 13 and the region of exon 15 of the $B R A F$ gene encompassing codon 600 , respectively. The oligonucleotide primers for sequencing of KRAS and BRAF are shown in Table I. Each exon was amplified by PCR using $0.5 \mathrm{Ag}$ of template DNA, sense and antisense primers, and an AmpliTaq Gold PCR kit (Applied Biosystems). A total of $50 \mu 1$ of reaction mixture was prepared according to the manufacturer's instructions and PCR was commenced at $94^{\circ} \mathrm{C}$ for $3 \mathrm{~min}$; followed by 35 cycles of $94^{\circ} \mathrm{C}$ for $30 \mathrm{sec}, 64^{\circ} \mathrm{C}$ or $60^{\circ} \mathrm{C}$ for $30 \mathrm{sec}$, and $72^{\circ} \mathrm{C}$ for $1 \mathrm{~min}$; with a final extension step for $5 \mathrm{~min}$. The PCR products were purified using an UltraClean PCR Clean-up kit (Mobio Laboratories, Solana Beach, CA) and subjected to direct sequencing using purified products and the same sets of primers in a capillary automatic sequencer (ABI PRISM 3100 Genetic Analyzer, Applied Biosystems). Sequence data were analyzed using the Basic Local Alignment Search Tool (BLAST) software located at the National Center for Biotechnology Information web site (http://www.ncbi.nlm.nih.gov) (12).

Statistical analysis. Correlation of KRAS mutations with the grade of histological differentiation and the cancer stage at surgery were analyzed using the $\chi^{2}$ test and Mann-Whitney test, respectively. Correlation of $K R A S$ mutations with patient age was also examined, after establishing that age had a normal distribution in the groups of patients with and without KRAS mutations. Mann-Whitney test was used to examine whether the population medians of the two independent groups differed significantly. Correlation of aberrant DNA hypermethylation of $h M L H 1$ with MSI was analyzed by the $\chi^{2}$ test.

\section{Results}

MSP analysis of samples of endometrial cancer showed aberrant $h M L H 1$ hypermethylation in 17 of the 44 cases (38.6\%) (Fig. 1, Table II). In MSI analysis, 31.8\% (14 samples), $6.8 \%$ (3 samples), and $61.4 \%$ (27 samples) of the cases were categorized as MSI-H, MSI-L and MSS (microsatellite

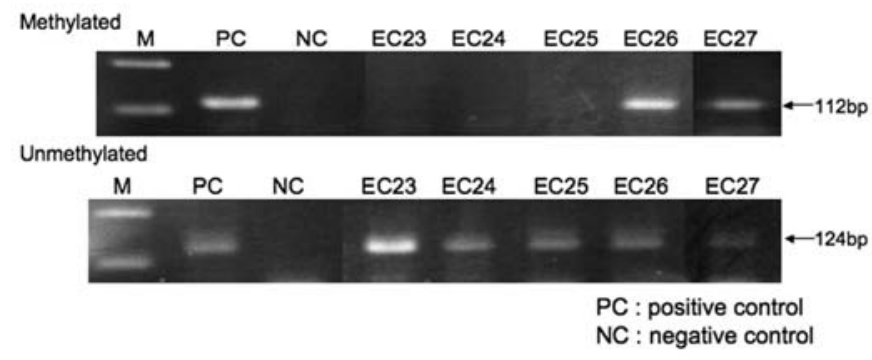

Figure 1. Detection of abnormal hypermethylation of the $h M L H 1$ gene in endometrial cancer using MSP analysis. The $112 \mathrm{bp}$ band indicating abnormal hypermethylation was found in EC26 and EC27.

stability), respectively; that is, $38.6 \%$ were judged to be MSI-positive. Aberrant hypermethylation of the $h M L H 1$ gene was found in a higher number of MSI-positive cases, with a statistically significant positive correlation $(\mathrm{p}=0.02)$ between abnormal hMLHI methylation and MSI (Table III).

A point mutation at codon 12 of KRAS was found in 3 (HEC-1B, HHUA and SNG-M) of the 8 endometrial cancerderived cell lines that were examined. These changes resulted in a G-D mutation in one cell line and G-V mutations in the other 2 cell lines. None of the cell lines had a point mutation at codon 13 of KRAS or at codon 600 of BRAF (Table IV). A point mutation at codon 12 of KRAS was observed in 6 of the 44 samples of endometrial cancer (13.6\%) (Fig. 2, Table II), with a similar mutation to those in the cultured cell lines (G-D or $\mathrm{V}$ ) in 5 of the 6 cases $(83.3 \%)$. The point mutation at codon 12 of KRAS showed no correlation with clinicopathological characteristics of endometrial cancer or with age upon development of cancer, but tended to occur more frequently in well-differentiated adenocarcinoma $(\mathrm{p}=0.1$, Table $\mathrm{V})$. There were no correlations among aberrant $h M L H 1$ hypermethylation, MSI, and point mutation at codon 12 of KRAS. No point mutation at codon 13 of KRAS (Table II) or at codon 600 of $B R A F$ (Table VI) was found in the 44 clinical samples of endometrial cancer.

\section{Discussion}

Carcinogenesis of colon cancer has been correlated with point mutation of the RAS/RAF family of genes in the MAP kinase pathway, suggesting the importance of mutation of these genes in an early stage of malignant change in colon cancer (1). Since mutations of KRAS and BRAF are observed in many MSI-positive cases of sporadic colon cancer with aberrant hypermethylation of the $h M L H 1$ gene, a correlation with MSI caused by decreased expression of hypermethylated hMLHI has been suggested (5). Similar decreased expression of $h M L H 1$ due to aberrant hypermethylation has been reported in endometrial cancer (14), but the correlation with point mutations of $K R A S$ and $B R A F$ remains unclear.

In the present study, aberrant hypermethylation of $h M L H 1$ was found in $38.7 \%$ of cases of sporadic endometrial cancer. Expression of $h M L H 1$ is significantly reduced by aberrant hypermethylation (14) and this may induce gene instability that can be detected as microsatellite instability (MSI). Previous studies have shown that about $13 \%$ of cases of sporadic colon cancer are MSI-positive (16) and that $84 \%$ of cases of MSI- 
Table II. Results of MSI analysis, MSP analysis, and analysis of $B R A F$ and $K R A S$ gene mutations in cases of endometrial cancer.

\begin{tabular}{|c|c|c|c|c|c|c|c|c|c|}
\hline \multirow[b]{2}{*}{ No. } & \multirow[b]{2}{*}{ Age } & \multirow[b]{2}{*}{ Type } & \multirow[b]{2}{*}{ Stage } & \multirow[b]{2}{*}{ Grade } & \multirow[b]{2}{*}{ MSI } & \multirow[b]{2}{*}{$h M L H 1$} & \multirow{2}{*}{$\begin{array}{c}\text { BRAF mutation } \\
\text { Codon } 600 \\
\text { GTG(V) }\end{array}$} & \multicolumn{2}{|c|}{ KRAS mutation } \\
\hline & & & & & & & & $\begin{array}{l}\text { Codon } 12 \\
\text { GGT(G) }\end{array}$ & $\begin{array}{c}\text { Codon } 13 \\
\text { GGC(G) }\end{array}$ \\
\hline $\mathrm{EC} 1$ & 52 & EM & $\mathrm{Ib}$ & G3 & MSI-H & M & GTG & GGT & GGC \\
\hline EC2 & 51 & EM & IIIc & G1 & MSI-H & $\mathrm{U}$ & GTG & GGT & GGC \\
\hline EC3 & 54 & AS & IIIc & G3 & MSI-H & M & GTG & GGT & GGC \\
\hline EC4 & 53 & EM & $\mathrm{Ib}$ & G3 & MSI-H & $\mathrm{U}$ & GTG & GGT & GGC \\
\hline EC5 & 69 & EM & IIIc & $\mathrm{G} 2$ & MSI-H & M & GTG & GGT & GGC \\
\hline EC6 & 55 & EM & IIIc & $\mathrm{G} 2$ & MSI-H & M & GTG & GGT & GGC \\
\hline EC7 & 54 & EM & Ia & G1 & MSI-H & $\mathrm{U}$ & GTG & GGT & GGC \\
\hline EC8 & 63 & EM & Ia & G1 & MSI-H & $\mathrm{M}$ & GTG & GGT & GGC \\
\hline EC9 & 58 & EM & $\mathrm{Ib}$ & $\mathrm{G} 2$ & MSI-H & M & GTG & GGT & GGC \\
\hline EC10 & 50 & EM & IIIa & G3 & MSI-H & $\mathrm{U}$ & GTG & GGT & GGC \\
\hline EC11 & 61 & EM & $\mathrm{Ib}$ & G1 & MSI-H & M & GTG & GGT & GGC \\
\hline $\mathrm{EC} 12$ & 55 & AS & $\mathrm{IVb}$ & G2 & MSI-H & $\mathrm{U}$ & GTG & GGT & GGC \\
\hline EC13 & 78 & EM & $\mathrm{Ib}$ & G3 & MSI-H & $\mathrm{U}$ & GTG & GGT & GGC \\
\hline EC14 & 65 & EM & $\mathrm{Ib}$ & $\mathrm{G} 2$ & MSI-H & M & GTG & GGT & GGC \\
\hline $\mathrm{EC} 15$ & 61 & EM & $\mathrm{IIb}$ & G1 & MSI-L & $\mathrm{U}$ & GTG & GGT & GGC \\
\hline EC16 & 57 & EM & $\mathrm{Ib}$ & G3 & MSI-L & $\mathrm{U}$ & GTG & GGT & GGC \\
\hline $\mathrm{EC} 17$ & 41 & EM & $\mathrm{Ib}$ & G1 & MSI-L & M & GTG & GGT & GGC \\
\hline EC18 & 50 & EM & Ia & G1 & MSS & $\mathrm{U}$ & GTG & GGT & GGC \\
\hline EC19 & 61 & EM & $\mathrm{Ib}$ & G1 & MSS & M & GTG & GAT(D) & GGC \\
\hline EC20 & 70 & EM & IIIc & G2 & MSS & $\mathrm{U}$ & GTG & GGT & GGC \\
\hline $\mathrm{EC} 21$ & 62 & AS & IIIa & G2 & MSS & $\mathrm{U}$ & GTG & GCT(A) & GGC \\
\hline $\mathrm{EC} 22$ & 40 & EM & IIa & G1 & MSS & $\mathrm{U}$ & GTG & GGT & GGC \\
\hline $\mathrm{EC} 23$ & 59 & EM & IIa & G3 & MSS & $\mathrm{U}$ & GTG & GGT & GGC \\
\hline EC24 & 80 & EM & IIIc & G3 & MSS & $\mathrm{U}$ & GTG & GGT & GGC \\
\hline EC25 & 54 & AS & $\mathrm{Ib}$ & G1 & MSS & $\mathrm{U}$ & GTG & GGT & GGC \\
\hline EC26 & 42 & EM & IIb & G1 & MSS & M & GTG & GGT & GGC \\
\hline $\mathrm{EC} 27$ & 71 & EM & IIIc & G3 & MSS & M & GTG & GGT & GGC \\
\hline EC28 & 60 & EM & $\mathrm{Ib}$ & G1 & MSS & $\mathrm{U}$ & GTG & GGT & GGC \\
\hline EC29 & 57 & EM & IIIa & G2 & MSS & $\mathrm{U}$ & GTG & GGT & GGC \\
\hline EC30 & 71 & EM & IIa & G1 & MSS & $\mathrm{U}$ & GTG & GTT(V) & GGC \\
\hline EC31 & 37 & EM & IIa & $\mathrm{G} 2$ & MSS & M & GTG & GGT & GGC \\
\hline EC32 & 47 & EM & IIIb & G1 & MSS & M & GTG & GAT(D) & GGC \\
\hline EC33 & 67 & EM & Ic & G2 & MSS & $\mathrm{U}$ & GTG & GGT & GGC \\
\hline EC34 & 53 & EM & Ia & G1 & MSS & M & GTG & GGT & GGC \\
\hline EC35 & 62 & AS & $\mathrm{Ib}$ & G1 & MSS & $\mathrm{M}$ & GTG & GGT & GGC \\
\hline EC36 & 56 & EM & IIIc & G3 & MSS & $\mathrm{U}$ & GTG & GGT & GGC \\
\hline EC37 & 71 & EM & $\mathrm{Ib}$ & G2 & MSS & $\mathrm{U}$ & GTG & GAT(D) & GGC \\
\hline EC38 & 53 & EM & $\mathrm{Ib}$ & G3 & MSS & $\mathrm{U}$ & GTG & GGT & GGC \\
\hline EC39 & 42 & AS & IIIc & G3 & MSS & $\mathrm{U}$ & GTG & GGT & GGC \\
\hline EC40 & 55 & EM & Ic & G3 & MSS & $\mathrm{U}$ & GTG & GGT & GGC \\
\hline EC41 & 34 & AS & IIIc & G1 & MSS & $\mathrm{U}$ & GTG & GTT(V) & GGC \\
\hline EC42 & 61 & EM & Ic & G1 & MSS & $\mathrm{U}$ & GTG & GGT & GGC \\
\hline EC43 & 61 & EM & Ic & G1 & MSS & $\mathrm{U}$ & GTG & GGT & GGC \\
\hline EC44 & 59 & EM & $\mathrm{Ib}$ & G1 & MSS & $\mathrm{U}$ & GTG & GGT & GGC \\
\hline
\end{tabular}


Table III. Correlation between MSI and abnormal hypermethylation of the $h M L H l$ gene in cases of endometrial cancer.

\begin{tabular}{lrrr}
\hline & & $h M L H 1$ & \\
& M & $\mathrm{U}$ & \\
\hline MSI & 10 & 7 & $\mathrm{p}=0.02$ \\
MSS & 7 & 20 & \\
\hline $\begin{array}{l}\text { MSI, microsatellite instability; MSS, microsatellite stability; M, methylated; } \\
\text { U, unmethylated. }\end{array}$ \\
\hline
\end{tabular}

Table IV. KRAS and BRAF gene mutations in human endometrial cancer-derived cell lines.

\begin{tabular}{|c|c|c|c|}
\hline & \multicolumn{2}{|c|}{$K R A S$} & \multirow{2}{*}{$\begin{array}{c}\text { BRAF } \\
\text { Codon } 600 \\
\text { GTG(V) }\end{array}$} \\
\hline & $\begin{array}{c}\text { Codon } 12 \\
\text { GCT(G) }\end{array}$ & $\begin{array}{c}\text { Codon } 13 \\
\text { GGC }(\mathrm{G})\end{array}$ & \\
\hline \multicolumn{4}{|l|}{ Cell lines } \\
\hline Hec108 & GGT & GGC & GTG \\
\hline SNG-II & GGT & GGC & GTG \\
\hline Ishikawa & GGT & GGC & GTG \\
\hline Hec-1B & GAT(D) & GGC & GTG \\
\hline HHUA & GTT(V) & GGC & GTG \\
\hline SNG-M & GTT(V) & GGC & GTG \\
\hline HOOUA & GGT & GGC & GTG \\
\hline KLE & GGT & GGC & GTG \\
\hline
\end{tabular}
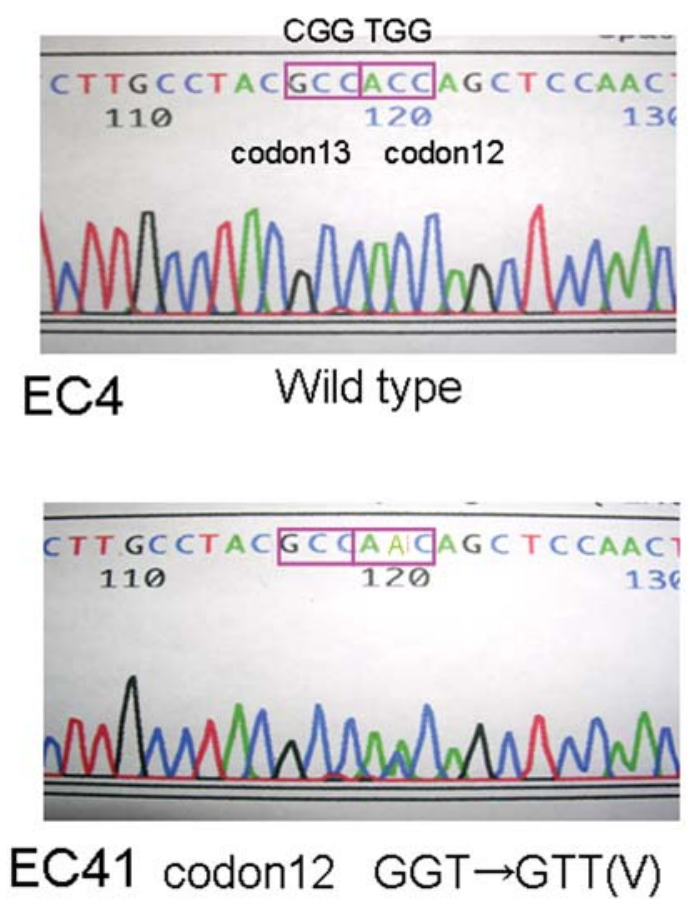

Table V. Correlation of KRAS gene mutations with clinicopathological factors in cases of endometrial cancer.

\begin{tabular}{lccccc}
\hline & \multicolumn{2}{c}{ Grade } & \multicolumn{2}{c}{ Stage } & Age \\
& G1,2 & G3 & I, II & III, IV & (average) \\
\hline KRAS codon 12 & & & & & \\
Mut & 6 & 0 & 3 & 3 & 57.7 \\
Wt & 25 & 13 & 26 & 12 & 57 \\
$\%$ Mut & 19.4 & 0 & 10.3 & 20 & \\
& $\mathrm{p}=0.1$ & & $\mathrm{p}=0.32$ & $\mathrm{p}=0.88$ \\
\hline
\end{tabular}

Statistical analysis was performed with the $\chi^{2}$ test and Mann-Whitney test. Mut, mutation; Wt, wild-type.

Table VI. Correlation of abnormal BRAF V600E genes with abnormal MMR and mutated KRAS genes.

\begin{tabular}{|c|c|c|c|c|c|c|}
\hline & \multicolumn{2}{|c|}{ MSI } & \multicolumn{2}{|c|}{$h M L H 1$} & \multicolumn{2}{|c|}{ KRAS codon 12} \\
\hline & Positive & Negative & M & $\mathrm{U}$ & Mut & Wt \\
\hline \multicolumn{7}{|l|}{$B R A F$} \\
\hline Mut & 0 & 0 & 0 & 0 & 0 & 0 \\
\hline $\mathrm{Wt}$ & 17 & 27 & 17 & 27 & 6 & 38 \\
\hline
\end{tabular}
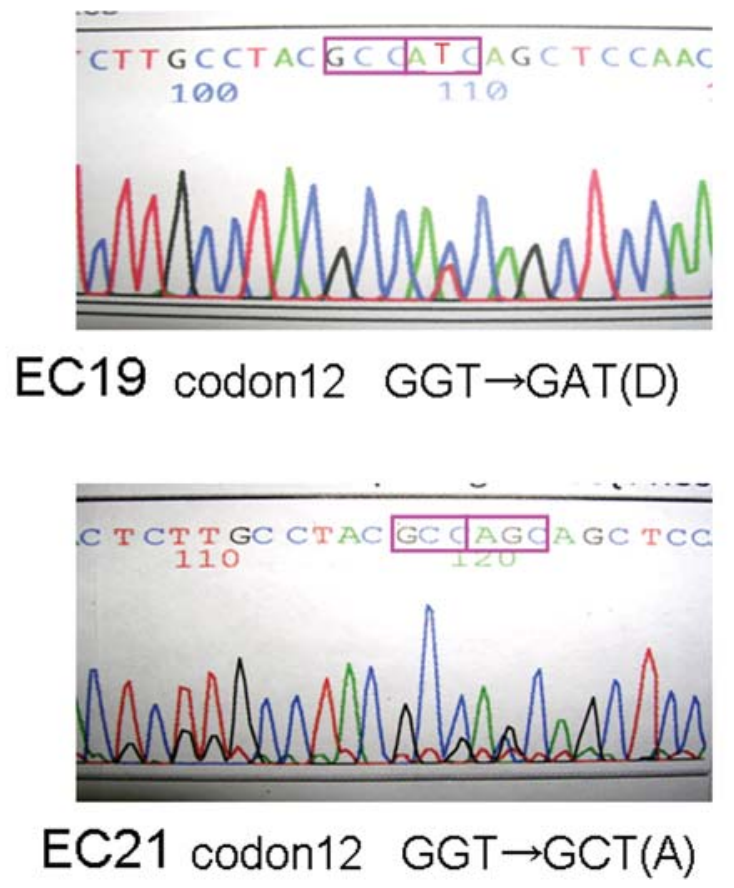

Figure 2. Analysis of point mutations of the KRAS gene in clinical samples of endometrial cancer. Three types of KRAS point mutation were detected at codon 12 . No point mutation was observed at codon 13 . 
positive colon cancer have aberrant $h M L H 1$ hypermethylation (17). In our analysis, MSI-positive cases accounted for $38.6 \%$ of all cases of sporadic endometrial cancer. Mutch et al reported an incidence of MSI-positive cancer of $29 \%$ (18), with MSI occurring at higher rates in endometrial cancer than in colon cancer, suggesting that gene instability caused by an abnormal MMR gene is important in carcinogenesis of endometrial cancer. Our analysis showed aberrant $h M L H 1$ hypermethylation in $58.8 \%(10 / 17)$ of MSI-positive cases, with a significant positive correlation between aberrant $h M L H 1$ hypermethylation and MSI-positive cases of sporadic endometrial cancer $(\mathrm{p}=0.02)$. Based on this, we suggest that aberrant $h M L H 1$ hypermethylation causes MSI in endometrial cancer, as also seen in colon cancer.

Point mutations of the KRAS gene at codons 12 have been reported to occur in $0-46 \%$ of endometrial cancers and the most frequent codon $12 \mathrm{KRAS}$ mutations are transitions from $\mathrm{G}$ to $\mathrm{D}$, to $\mathrm{V}$ (19). Point mutations of the KRAS gene at codons 12 and 13 have been reported in $5.9 \%$ and $2.9 \%$ of patients with endometrial cancer, respectively, and the mutation showed a positive correlation with age upon development (20). Mutch et al found point mutations at codons 12, 13, and 61 of $K R A S$ in $19.9 \%, 3.4 \%$ and $0.7 \%$ of cases of endometrial cancer, respectively, with a correlation with age upon development and a high rate of mutation in MSI-positive cases (18). In our analysis, point mutation at codon 12 was confirmed in $14 \%$ of cases, but none were observed at codon 13 and KRAS mutation showed no correlation with age. The incidence of well-differentiated adenocarcinoma tended to be high among cases with a mutation of KRAS, but the relationship was not significant, and there was no tendency for a higher rate of mutation of KRAS in MSI-positive cases. Point mutation of $K R A S$ has been found in $51 \%$ of cases with colon cancer, and the rate in endometrial cancer is much lower (1). Mutation of $K R A S$ may have some correlation with carcinogenesis in patients who develop sporadic endometrial cancer at an old age, but the current and previous results suggest that this mutation is not important for carcinogenesis in other cases of sporadic endometrial cancer.

Feng et al found mutation of the BRAF gene in $21 \%$ of cases of endometrial cancer, and proposed a correlation with decreased expression of the MMR gene (12). In contrast, Salvesen et al found the activating BRAF V600E mutation in only $2 \%$ of cases of endometrial cancer, and a consensus has not been obtained regarding the correlation between carcinogenesis of endometrial cancer and $B R A F$ mutation (13). In our analysis, no $B R A F$ V600E mutation was observed in cases of sporadic endometrial cancer. Collectively, these data suggested that the BRAF V600E mutation occurs at an extremely low rate in endometrial cancer, and thus may not be important for carcinogenesis of sporadic endometrial cancer. In contrast, the $B R A F \mathrm{~V} 600 \mathrm{E}$ mutation occurs at a high rate in sporadic colon cancer, and may be useful diagnostically to rule out the possibility of a hereditary tumor. However, this mutation is not useful in diagnosis of sporadic endometrial cancer.

Since we did not find a $B R A F$ V600E mutation in our analysis, there was clearly no correlation between the $B R A F$ V600E mutation and aberrant hypermethylation of $h M L H 1$ or MSI. Decreased expression of $h M L H 1$ due to aberrant hyper- methylation could cause gene instability, with a high rate of mutation of a target gene such as $B R A F$. However, our results suggest that $B R A F$ is not the target of abnormal MMR in sporadic endometrial cancer. On the other hand, since aberrant hypermethylation of $h M L H 1$ and MSI were detected at high rates in sporadic endometrial cancer patients, an abnormal MMR system is clearly associated with the mechanism of carcinogenesis in endometrial cancer. Identification of the new target gene for abnormal MMR will be extremely important for clarification of this mechanism.

\section{Acknowledgments}

This study was supported by the Japan Society for the Promotion of Science (JSPS) through a Grant-in-Aid for Scientific Research (KAKENHI); a Grant-in-Aid for Young Scientists (B) (19791163); the Sato Memorial Foundation for Cancer Research; The Public Trust Fund For Clinical Cancer Research; the Keio University Medical Science Fund through a Research Grants for Life Sciences and Medicine; and a Keio University Grant-in-Aid for Encouragement of Young Medical Scientists.

\section{References}

1. Rajagopalan H, Bardelli A, Lengauer C, Kinzler KW, Vogelstein B and Velculescu VE: RAF/RAS oncogenes and mismatch-repair status. Nature 418: 934, 2002.

2. Bronner CE, Baker SM, Morrison PT, Warren G, Smith LG, Lescoe MK, Kane M, Earabino C, Lipford J, Lindblom A, Tannergard P, Bollag RJ, Godwin AR, Ward DC, Nordenskj M, Fishel R, Kolodner R and Liskay LM: Mutation in the DNA mismatch repair gene homologue hMLH1 is associated with hereditary non-polyposis colon cancer. Nature 368: 258-261, 1994.

3. Simpkins SB, Swisher EM, Mutch DG, Gersell DJ, Kovatich AJ, Palazzo JP, Fishel R and Goodfellow P: MLH1 promoter methylation and gene slicing is the primary cause of microsatellite instability in sporadic endometrial cancers. Hum Mol Genet 8: 661-666, 1999.

4. Thibodeau SN, Bren G and Schaid D: Microsatellite instability in cancer of the proximal colon. Science 260: 816-819, 1993.

5. Oliveira C, Westra JL, Arango D, Ollikainen M, Domingo E, Ferreira A, Velho S, Niessen R, Lagerstedt K, Alhopuro P, Laiho P, Veiga I, Teixeira MR, Ligtenberg M, Kleibeuker JH, Sijmons RH, Plukker JT, Imai K, Lage P, Hamelin R, Albuquerque C, Schwartz S Jr, Lindblom A, Peltomaki P, Yamamoto H, Aaltonen LA, Seruca R and Hofstra RM: Distinct patterns of KRAS mutations in colorectal carcinomas according to germline mismatch repair defects and hMLH1 methylation status. Hum Mol Genet 13: 2303-2311, 2004.

6. Koinuma K, Shitoh K, Miyakura Y, Furukawa T, Yamashita Y, Ota J, Ohki R, Choi YL, Wada T, Konishi F, Nagai H and Mano H: Mutation of BRAF are associated with extensive hMLH1 promoter methylation in sporadic colorectal carcinomas. Int J Cancer 108: 237-242, 2004.

7. Maldonado JI, Fridlyand J, Patel H, Jain AN, Busam K, Kageshita T, Ono T, Albertson DG, Pinkel D and Bastian BC: Determinants if BRAF mutations in primary melanomas. J Natl Cancer Inst 95: 1878-1880, 2003.

8. Cohen Y, Xing M, Mambo E, Guz Z, Wu G, Trink B, Beller U, Westra WH, Ladenson PW and Sidransky D: BRAF mutation in papillary thyroid. J Natl Cancer Inst 95: 625-627, 2003.

9. Singer G, Oldt R III, Cohen Y, Wang BG, Sidransky D, Kurman RJ and Shih IeM: Mutation in BRAF and KRAS characterize the development if low grade ovarian serous carcinoma. J Natl Cancer Inst 95: 484-486, 2003.

10. Wellbrock C, Karasarides M and Marais R: The RAF proteins take centre stage. Nat Rev Mol Cell Biol 5: 875-885, 2004.

11. Deng G, Bell I, Crawley S, Gum J, Tersiman JP, Allen BA, Truta B, Sleisenger $\mathrm{MH}$ and Kim YS: $B R A F$ mutation is frequently present in sporadic colorectal cancer with methylated hMLH1, but not in hereditary nonpolyposis colorectal cancer. Clin Cancer Res 10: 191-195, 2004. 
12. Feng YZ, Shiozawa T, Miyamoto T, Kashima H, Kurai M, Suzuki A and Konishi I: BRAF mutation in endometrial carcinoma and hyperplasia: correlation with KRAS and p53 mutations and mismatch repair protein expression. Clin Cancer Res 11: 6133-6138, 2005.

13. Salvesen HB, Kumar R, Stefansson I, Angelini S, MacDonald N Smeds J, Jacobs IJ, Hemminki K, Das S and Akslen LA: Low frequency if BRAF and CDKN2A mutations in endometrial cancer. Int J Cancer 115: 930-934, 2005.

14. Banno K, Yanokura M, Susumu N, Kawaguchi M, Hirao N, Hirasawa A, Tsukazaki K and Aoki D: Relationship of the aberrant DNA hypermethylation of cancer-related genes with carcinogenesis of endometrial cancer. Oncol Rep 16: 1189-1196, 2006.

15. Hirasawa A, Aoki D, Inoue J, Imoto I, Susumu N, Sugano K, Nozawa $\mathrm{S}$ and Inazawa J: Unfavorable prognostic factors associated with high frequency of microsatellite instability and comparative genomic hybridization analysis in endometrial cancer. Clin Cancer Res 9: 5675-5682, 2003.
16. Aaltonen LA, Peltomäki P, Leach FS, et al: Clues to the pathogenesis of familial colorectal cancer. Science 260: 812-816, 1993.

17. Herman JG, Umar A, Polyak K, Graff JR, Ahuja N, Issa JP, Markowitz S, Willson JK, Hamilton SR, Kinzler KW, Kane MF, Kolodner RD, Vogelstein B, Kunkel TA and Baylin SB: Incidence and functional consequences of hMLH1 promoter hypermethylation in colorectal carcinoma. Proc Natl Acad Sci USA 95: 6870-6875, 1998

18. Mutch DG, Powell MA, Mallon MA and Goodfellow PJ: RAS/ RAF mutation and defective DNA mismatch repair in endometrial cancers. Am J Obstet Gynecol 190: 935-942, 2004.

19. Mammas IN, Zafiropoulos A and Spandidos DA: Involvement of the ras genes in female genital tract cancer. Int J Oncol 26: 1241-1255, 2005.

20. Pappa KI, Choleza M, Markaki S, Giannikaki E, Kyroudi A, Vlachos G, Voulgaris Z and Anagnou NP: Consistent absence of BRAF mutations in cervical and endometrial cancer despite KRAS mutation status. Gynecol Oncol 100: 596-600, 2006. 